\title{
Fusibacter paucivorans gen. nov., sp. nov., an anaerobic, thiosulfate-reducing bacterium from an oil-producing well
}

\author{
Gilles Ravot, ${ }^{1}$ Michel Magot, ${ }^{2}$ Marie-Laure Fardeau, ${ }^{1}$ Bharat K. C. Patel, ${ }^{3}$ \\ Pierre Thomas, ${ }^{4}$ Jean-Louis Garcia ${ }^{1}$ and Bernard Ollivier ${ }^{1}$
}

\begin{abstract}
Author for correspondence: Bernard Ollivier. Tel: +334918285 76. Fax: +33491828570 .
\end{abstract} e-mail: ollivier@esil.univ-mrs.fr

\author{
1 Laboratoire ORSTOM de \\ Microbiologie des \\ Anaérobies, Université de \\ Provence, CESB-ESIL case \\ 925, 163 Avenue de \\ Luminy, 13288 Marseille \\ Cedex 9, France \\ 2 Sanofi Recherche, Groupe \\ Elf-Aquitaine, 31676 \\ Labège Cedex, France \\ 3 School of Biomolecular \\ and Biomedical Sciences, \\ Faculty of Science, Griffith \\ University, Brisbane, \\ Queensland 4111, \\ Australia \\ 4 Département de Biologie, \\ Université de la \\ Méditerranée, 13288 \\ Marseille cedex 9, France
}

\begin{abstract}
A strictly anaerobic, halotolerant, spindle-shaped rod, designated strain SEBR 4211', was isolated from an African saline oil-producing well. Cells stain Grampositive, which was confirmed by electron microscopy observations. Strain SEBR $4211^{\top}$ was motile by means of one to four peritrichous flagella, had a $\mathrm{G}+\mathrm{C}$ content of $43 \mathrm{~mol} \%$ and grew optimally at $37{ }^{\circ} \mathrm{C}$, pH 7.3, with 0 to $3 \%$ (w/v) $\mathrm{NaCl}$. It utilized a limited number of carbohydrates (cellobiose, glucose, fructose, mannitol and ribose) and produced acetate, butyrate, $\mathrm{CO}_{2}$ and $\mathrm{H}_{2}$ as end products from glucose fermentation. It reduced thiosulfate to sulfide. In the presence of thiosulfate, a decrease in butyrate and an increase in acetate production was observed. Phylogenetically, strain SEBR 4211' was related to members of the low G+C Clostridiales order with Clostridium halophilum as the closest relative (16S rDNA sequence similarity of $90 \%$ ). On the basis of phenotypic, genotypic and phylogenetic characteristics of the isolate, it is proposed to designate it as a new species of a new genus, Fusibacter gen. nov., as Fusibacter paucivorans sp. nov. The type strain is SEBR $4211^{\top}$ (=DSM 12116').
\end{abstract}

Keywords: Fusibacter paucivorans, oil-producing well, thiosulfate reduction, taxonomy

\section{INTRODUCTION}

Though members of the domain Archaea are known to thrive in oilfield ecosystems (L'Haridon et al., 1995; Stetter et al., 1993), it now appears that fermentative bacteria could be the dominant microbial community in these ecosystems (Davydova-Charakhch'yan et al., 1993; Fardeau et al., 1993, 1996; Holloway et al., 1980; Jeanthon et al., 1995; L'Haridon et al., 1995; Ravot et al., 1995a; Stetter et al., 1993). We recently isolated from oilfields fermentative bacteria that have the ability to reduce thiosulfate to sulfide during growth on organic compounds (Fardeau et al., 1993; Magot et al., 1997a, b; Ravot et al., 1995a, b, 1997). The presence of thiosulfate is thought to increase biocorrosion risks in oilfield installations (Crolet \& Magot, 1996; Magot et al., 1994), and we provided recently the first experimental evidence of the in-

The GenBank accession number for the 16S rRNA sequence of strain SEBR $4211^{\top}$ is AF050099. volvement of a non-carbohydrate-utilizing peptideutilizing thiosulfate-reducing bacterium, Dethiosulfovibrio peptidovorans, in steel corrosion (Magot et al., 1997b). These results provided a strong incentive to try to isolate other thiosulfate-utilizing micro-organisms from the oilfield environment.

We report here on the isolation of a new halotolerant thiosulfate-reducing bacterium having phenotypic and phylogenetic characteristics consistent with its placement in a new genus as a new species within the Clostridiales as Fusibacter paucivorans gen. nov., sp. nov.

\section{METHODS}

Sample source and sample collection. Strain SEBR 4211 was isolated from a reservoir water sample from an offshore oil-producing well (Emeraude oilfield) in Congo, Central Africa. The in situ temperature was $35-40^{\circ} \mathrm{C}$ and the concentration of sodium chloride was $40 \mathrm{~g} \mathrm{l}^{-1}$ (total salinity, $53 \mathrm{~g}^{-1}$ ). A 11 sample was collected at the well head as 
described by Bernard et al. (1992), and culture broths were immediately inoculated.

Medium, enrichment and isolation. Enrichments were performed at $30^{\circ} \mathrm{C}$ without agitation by inoculating directly a $2 \mathrm{ml}$ sample from the reservoir water into a basal medium containing (per litre of distilled water) $1 \mathrm{~g} \mathrm{NH}_{4} \mathrm{Cl}, 0.3 \mathrm{~g}$ $\mathrm{K}_{2} \mathrm{HPO}_{4}, \quad 0.3 \mathrm{~g} \quad \mathrm{KH}_{2} \mathrm{PO}_{4}, \quad 3 \mathrm{~g} \quad \mathrm{MgCl}_{2} .6 \mathrm{H}_{2} \mathrm{O}, \quad 0.1 \mathrm{~g}$ $\mathrm{CaCl}_{2} .2 \mathrm{H}_{2} \mathrm{O}, 40 \mathrm{~g} \mathrm{NaCl}, 1 \mathrm{~g} \mathrm{KCl}, 0.5 \mathrm{~g}$ cysteine- $\mathrm{HCl}, 0.5 \mathrm{~g}$ $\mathrm{CH}_{3} \mathrm{COONa}, 1 \mathrm{~g}$ yeast extract (Difco Laboratories), $1 \mathrm{~g}$ bioTrypticase (bioMérieux), $3.6 \mathrm{~g}$ glucose, $10 \mathrm{ml}$ of the trace element solution of Balch et al. (1979) and $0.1 \mathrm{mg}$ resazurin. The $\mathrm{pH}$ was adjusted to $\mathrm{pH} 7 \cdot 3$ with $10 \mathrm{M} \mathrm{KOH}$. The medium was boiled under a stream of $\mathrm{O}_{2}$-free $\mathrm{N}_{2}$ gas and cooled to room temperature. Five or $20 \mathrm{ml}$ aliquots were dispensed into Hungate tubes or serum bottles, respectively, under a stream of $\mathrm{N}_{2} / \mathrm{CO}_{2}(4: 1, \mathrm{v} / \mathrm{v})$, and the vessels were sealed and autoclaved for $45 \mathrm{~min}$ at $110^{\circ} \mathrm{C}$. Prior to inoculation, $\mathrm{Na}_{2} \mathrm{~S} .9 \mathrm{H}_{2} \mathrm{O}, \mathrm{NaHCO}_{3}$ and sodium thiosulfate were injected from sterile stock solutions, to final concentrations of $0.04 \%(\mathrm{w} / \mathrm{v}), 0.2 \%$ and $20 \mathrm{mM}$, respectively. The final $\mathrm{pH}$ was $\mathrm{pH} 7 \cdot 2$. Unless otherwise indicated the basal medium was used throughout these studies. The strain was purified by repeated isolation on Petri dishes containing the same medium solidified with $1.6 \%(\mathrm{w} / \mathrm{v})$ agar as already reported (Magot et al., 1997a, b; Ravot et al., 1997). Incubation was performed in an anaerobic glove box at $30^{\circ} \mathrm{C}$.

Growth conditions. All growth experiments were performed in duplicate, using Hungate tubes (Hungate, 1969) containing the basal medium unless otherwise indicated. For $\mathrm{pH}$ growth experiments, the medium was adjusted to different $\mathrm{pH}$ values by injecting $\mathrm{NaHCO}_{3}$ or $\mathrm{Na}_{2} \mathrm{CO}_{3}$ into Hungate tubes from $10 \%(\mathrm{w} / \mathrm{v})$ sterile anaerobic stock solutions. The temperature range for growth was determined using the culture medium adjusted to the $\mathrm{pH}$ optimum for growth. For studies on sodium chloride requirements, sodium chloride was weighed directly into Hungate tubes, and the basal medium dispensed into the tubes as described above. The strain was subcultured at least once under the same experimental conditions prior to inoculation for each growth experiment.

Tests for sporulation. The presence of spores was determined by microscopic examination of the culture at different phases of growth. The presence of heat-resistant spores was determined by heating at $80^{\circ} \mathrm{C}$ for $10-20 \mathrm{~min}$, at $90^{\circ} \mathrm{C}$ for 5-10 min and at $100^{\circ} \mathrm{C}$ for 10 min a culture previously grown in a rich medium containing $20 \mathrm{mM}$ glucose, and $5 \mathrm{~g}$ yeast extract $1^{-1}$ and $5 \mathrm{~g}$ bio-Trypticase $\mathrm{l}^{-1}$ in distilled water.

Substrate-utilization tests. For substrate-utilization tests, the basal medium without glucose was used. The substrates (D-arabinose, cellobiose, dulcitol, D-fructose, D-galactose, Dglucose, lactose, maltose, D-mannitol, D-mannose, D-melibiose, D-raffinose, L-rhamnose, D-ribose, D-sorbitol, L-sorbose, sucrose, D-trehalose, DL-xylose, cellulose, starch, formate, acetate, butyrate, lactate, propionate) were injected from autoclaved stock solutions into Hungate tubes to a final concentration of $20 \mathrm{mM}$ for sugars and $10 \mathrm{mM}$ for organic and fatty acids. Formate and methanol were added to obtain a final concentration of $40 \mathrm{mM}$, whereas peptides, Casamino acids and gelatin were added at a final concentration of $5 \mathrm{~g} \mathrm{l}^{-1}$. The substrates were tested in the presence or absence of sodium thiosulfate (final concentration, $20 \mathrm{mM}$ ). To test for electron acceptors, $20 \mathrm{mM}$ sodium thiosulfate, $20 \mathrm{mM}$ sodium sulfate and $2 \%(\mathrm{w} / \mathrm{v})$ elemental sulfur were added to the medium.
Light and electron microscopy. Light microscopy was performed as described by Cayol et al. (1994). For electron microscopy, exponentially-grown cells were negatively stained with $1 \%(\mathrm{w} / \mathrm{v})$ sodium phosphotungstate $(\mathrm{pH} 7 \cdot 2)$. For preparation of thin sections, exponentially-grown cells were centrifuged and fixed for $45 \mathrm{~min}$ in $4 \%(\mathrm{w} / \mathrm{v})$ glutaraldehyde prepared in $25 \mathrm{mM}$ cacodylate $/ \mathrm{HCl}$ buffer ( $\mathrm{pH} 6.0)$ containing $2 \%(\mathrm{w} / \mathrm{v}) \mathrm{NaCl}$. Then the cells were washed in the same buffer containing $0.3 \mathrm{M}$ sucrose and $2 \%$ $(\mathrm{w} / \mathrm{v}) \mathrm{NaCl}$ and postfixed for $1 \mathrm{~h}$ in $1 \%(\mathrm{w} / \mathrm{v})$ osmium tetroxide prepared in the same buffer with $0.25 \mathrm{M}$ sucrose and $2 \% \mathrm{NaCl}$. Then the cells were diluted and washed with water, embedded in $2 \%(\mathrm{w} / \mathrm{v})$ agarose and stained with $4 \%$ $(\mathrm{w} / \mathrm{v})$ uranyl acetate. The agarose was cut into small cubes, dehydrated in acetone and embedded in Araldite. Thin sections were stained with $5 \%(\mathrm{w} / \mathrm{v})$ uranyl acetate for $20 \mathrm{~min}$ and with $2 \%(\mathrm{w} / \mathrm{v})$ lead citrate for $10 \mathrm{~min}$. Micrographs were taken with a Hitachi model H600 electron microscope at an accelerating voltage of $75 \mathrm{kV}$.

Analytical techniques. Growth was measured by inserting Hungate tubes directly into a model UV-160A spectrophotometer (Shimadzu) and measuring the optical density at $580 \mathrm{~nm}$. Sulfide was determined photometrically as collodial CuS by using the method of Cord-Ruwisch (1985). Hydrogen and fermentation products (alcohols, and volatile and non-volatile fatty acids) were measured as described by Fardeau et al. (1993).

Determination of $\mathbf{G}+\mathbf{C}$ content of DNA. The $\mathrm{G}+\mathrm{C}$ content of DNA was determined by the DSMZ (Deutsche Sammlung von Mikroorganismen und Zellkulturen, Braunschweig, Germany). The DNA was isolated and purified by chromatography on hydroxyapatite and the $\mathbf{G}+\mathrm{C}$ content was determined by using HPLC as described by Mesbah et al. (1989). Non-methylated lambda DNA (Sigma) was used as the standard.

165 rDNA sequence studies. The methods for the purification and extraction of DNA and the amplification and sequencing of the 16S rRNA gene have been described previously (Andrews \& Patel, 1996; Love et al., 1993; Redburn \& Patel, 1993). The 16S rRNA gene sequence, which we determined, was manually aligned with reference sequences of various members of the domain Bacteria by using the editor ae2 (Maidak et al., 1996). Reference sequences were obtained from the Ribosomal Database Project (Maidak et al., 1996), EMBL and GenBank databases. Positions of sequence and alignment uncertainty were omitted from the analysis. A phylogenetic analysis was performed by using the various programs that are part of the PHYLIP package (Felsenstein, 1993) as described below. The pairwise evolutionary distances based on 1229 unambiguous nucleotides were computed by using the method of Jukes \& Cantor (1969) and dendrograms were constructed from these distances by using the neighbour-joining method.

\section{RESULTS}

\section{Enrichment and isolation}

One enrichment culture on medium containing glucose as the energy source was positive and $\mathrm{H}_{2} \mathrm{~S}$ was detected after incubation at $30^{\circ} \mathrm{C}$ for $7 \mathrm{~d}$. Microscopic examination showed the presence of different morphological types of micro-organisms including spindle-shaped rods. The latter formed colonies on Petri dishes after $5 \mathrm{~d}$ incubation at $30^{\circ} \mathrm{C}$. Single colonies were picked 

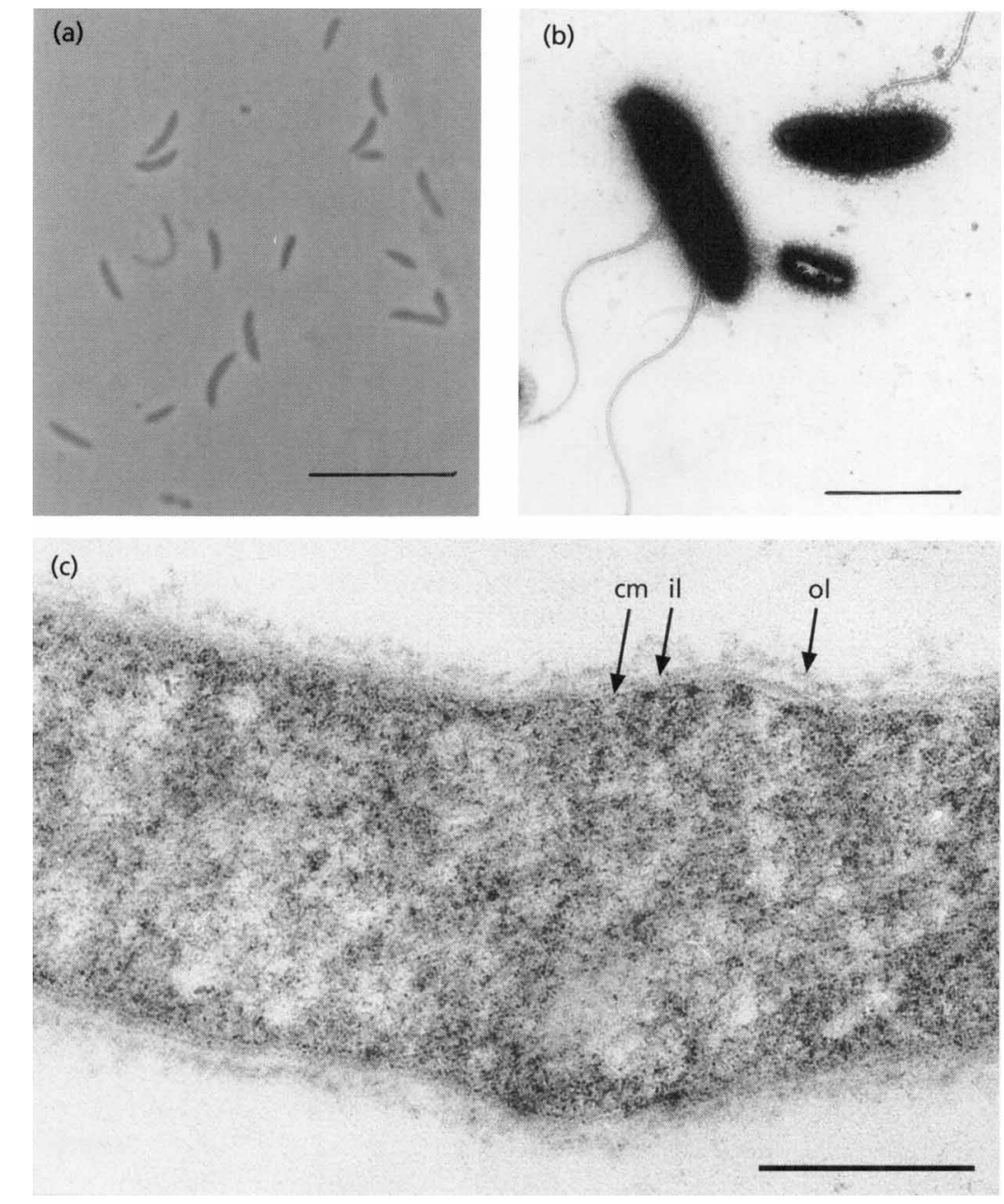

Fig. 1. (a) Phase-contrast micrograph of strain SEBR $4211^{\top}$ (bar, $10 \mu \mathrm{m}$ ); (b) electron micrograph of a negatively stained culture of strain SEBR $4211^{\top}$ showing one or two pertrichous flagella (bar, $2 \mu \mathrm{m}$ ); (c) electron micrograph of an ultrathin section of strain SEBR $4211^{\mathrm{T}}$ showing the cytoplasmic membrane $(\mathrm{cm})$, the inner layer (il) and the outer layer (ol) (bar, $0.2 \mu \mathrm{m}$ ). and reinoculated twice before the culture was tested for purity. A spindle-shaped bacterium, designated SEBR $4211^{\mathrm{T}}$ was used for further studies.

\section{Morphology}

White regular colonies (1 $\mathrm{mm}$ in diameter) were obtained after $8 \mathrm{~d}$ incubation at $30^{\circ} \mathrm{C}$. Strain SEBR $4211^{\mathrm{T}}$ was a spindle-shaped rod. The cells were $1 \times 2-5 \mu \mathrm{m}$ and occurred singly or in pairs (Fig. 1a). Each cell possessed one to four peritrichous flagella (Fig. 1b). Cells stained Gram-positive. Electron microscopy of sections of strain SEBR $4211^{\mathrm{T}}$ revealed an atypical Gram-positive cell wall with a thin inner layer and a loose undulating outer layer (Fig. 1c). Spores were never observed. In addition, no growth was observed after the culture was heated at $100^{\circ} \mathrm{C}$ for 10 $\min$.

\section{Optimum growth conditions}

Strain SEBR $4211^{\mathrm{T}}$ was anaerobic since it did not grow in oxidized medium (oxidation was indicated by the pink colour of the resazurin). It grew at temperatures ranging from 20 to $45^{\circ} \mathrm{C}$, with an optimum at $37^{\circ} \mathrm{C}$ (Fig. 2a). The isolate grew at sodium chloride concentrations ranging from 0 to $100 \mathrm{~g} \mathrm{NaCl} \mathrm{l}^{-1}$, with an optimum between 0 and $30 \mathrm{~g} \mathrm{NaCl} \mathrm{l}^{-1}$ (Fig. 2b). The optimum $\mathrm{pH}$ for growth was $7 \cdot 3$, and growth occurred between $\mathrm{pH} 5.7$ and 8.0 (Fig. 2c).

\section{Substrates for growth}

No growth was obtained in the basal medium in the absence of glucose. Yeast extract was required for growth on carbohydrates and could not be replaced by bio-Trypticase. The following sugars were used as energy sources: D-cellobiose, fructose, glucose, Dmannitol and D-ribose. Strain SEBR $4211^{\mathrm{T}}$ could not utilize arabinose, dulcitol, galactose, lactose, maltose, mannose, melibiose, raffinose, rhamnose, sorbitol, sorbose, sucrose, trehalose, xylose, cellulose, starch, formate, acetate, butyrate, lactate, propionate, methanol, bio-Trypticase, Casamino acids or gelatin. Acetate, butyrate, $\mathrm{CO}_{2}$ and $\mathrm{H}_{2}$ were produced during glucose fermentation (Table 1). The presence of thiosulfate did not affect the substrate utilization pattern. 

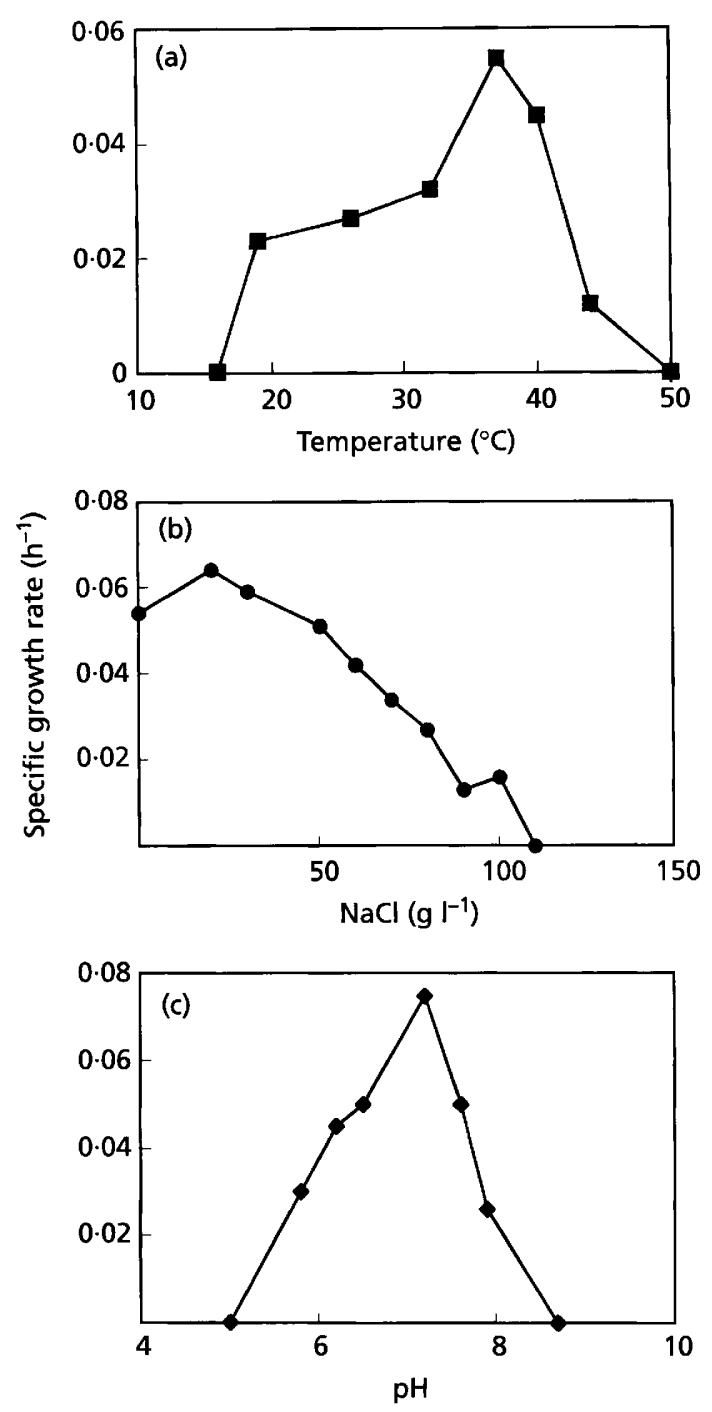

Fig. 2. Effect of (a) temperature $(\mathrm{pH} \mathrm{7 \cdot 3,} \mathrm{no} \mathrm{NaCl}$ ), (b) $\mathrm{NaCl}$ $\left(37^{\circ} \mathrm{C}, \mathrm{pH} 7 \cdot 3\right)$ and (c) $\mathrm{pH}\left(37^{\circ} \mathrm{C}\right.$, no $\left.\mathrm{NaCl}\right)$ on the growth of strain SEBR $4211^{\top}$ cultivated in basal medium.

\section{Effect of electron acceptors}

Strain SEBR $4211^{\mathrm{T}}$ used thiosulfate and sulfur but not sulfate as an electron acceptor. Hydrogen inhibited the growth of strain SEBR $4211^{\mathrm{T}}$ but inhibition was relieved in the presence of thiosulfate. Growth was not observed on hydrogen as the sole energy source in the presence of thiosulfate as the electron acceptor and acetate $(1 \mathrm{mM})$ as the carbon source. A decrease in butyrate production and an increase in acetate production were observed in the presence of thiosulfate (Table 1).

\section{$G+C$ content of DNA and 16S rDNA sequence analysis}

The $\mathrm{G}+\mathrm{C}$ content of DNA of isolate SEBR $4211^{\mathrm{T}}$ was $43 \mathrm{~mol} \%$ (as determined by HPLC). Using 12 primers, we determined an almost complete sequence consisting of 1525 bases of the 16S rRNA gene of strain SEBR $4211^{\mathrm{T}}$ (corresponding to Escherichia coli positions 8-1542). Phylogenetic analysis showed that strain SEBR $4211^{\mathrm{T}}$ was a member of low $\mathrm{G}+\mathrm{C}$ content Gram-positive branch and grouped with members of cluster XI. The closest relatives were Clostridium halophilum (similarity of $90 \%$ ), 'Clostridium aminobutyricum' and Clostridium felsineum (mean similarity of $89 \%$ ) (Fig. 3).

\section{DISCUSSION}

Strain SEBR $4211^{\mathrm{T}}$ isolated from oil reservoir water reduces thiosulfate to sulfide. Thiosulfate reduction is a common physiological trait exhibited by many fermentative mesophilic, thermophilic and hyperthermophilic micro-organisms of the domain Bacteria originating from oilfield ecosystems (Fardeau et al., 1993, 1997; Jeanthon et al., 1995; Magot et al., 1994, 1997a, b; Ravot et al., 1995a, b, 1997). Interestingly, thiosulfate has been detected in oilfield facilities where it is thought to increase biocorrosion (Crolet \& Magot, 1996; Magot et al., 1994), but the ecological significance of thiosulfate reduction in oil reservoirs is so far unknown.

Phylogenetic analysis of $16 \mathrm{~S}$ rRNA indicates that strain SEBR $4211^{\mathrm{T}}$ is a member of the Clostridium phylum (Cato et al., 1986) and belongs to cluster XI, which includes Clostridium lituseburense and its related taxa (Collins et al., 1994). This cluster is taxonomically heterogeneous, containing non-spore forming species

Table 1. Fermentation of glucose in the presence and absence of thiosulfate by strain SEBR $4211^{\top}$

\begin{tabular}{|c|c|c|c|c|c|c|c|}
\hline \multirow[t]{2}{*}{ Culture conditions } & \multirow{2}{*}{$\begin{array}{l}\text { Amount of } \\
\text { substrate } \\
\text { used }(\mathrm{mM})\end{array}$} & \multicolumn{5}{|c|}{ End product formed (mM) } & \multirow{2}{*}{$\begin{array}{c}\text { Ratio of acetate } \\
\text { produced/sugar } \\
\text { consumed }\end{array}$} \\
\hline & & Acetate & Butyrate & $\mathrm{CO}_{2}^{*}$ & $\mathbf{H}_{2}^{*}$ & $\mathbf{H}_{2} \mathrm{~S}$ & \\
\hline Glucose & $5 \cdot 0$ & 1.6 & $4 \cdot 0$ & $10 \cdot 2$ & $15 \cdot 2$ & 0 & $0 \cdot 32$ \\
\hline Glucose + thiosulfate $\dagger$ & 9.9 & $12 \cdot 2$ & $3 \cdot 0$ & $20 \cdot 4$ & $7 \cdot 1$ & 11.5 & $1 \cdot 23$ \\
\hline
\end{tabular}

* Millimolar equivalents.

† Sodium thiosulfate was added at a final concentration of $20 \mathrm{mM}$. 


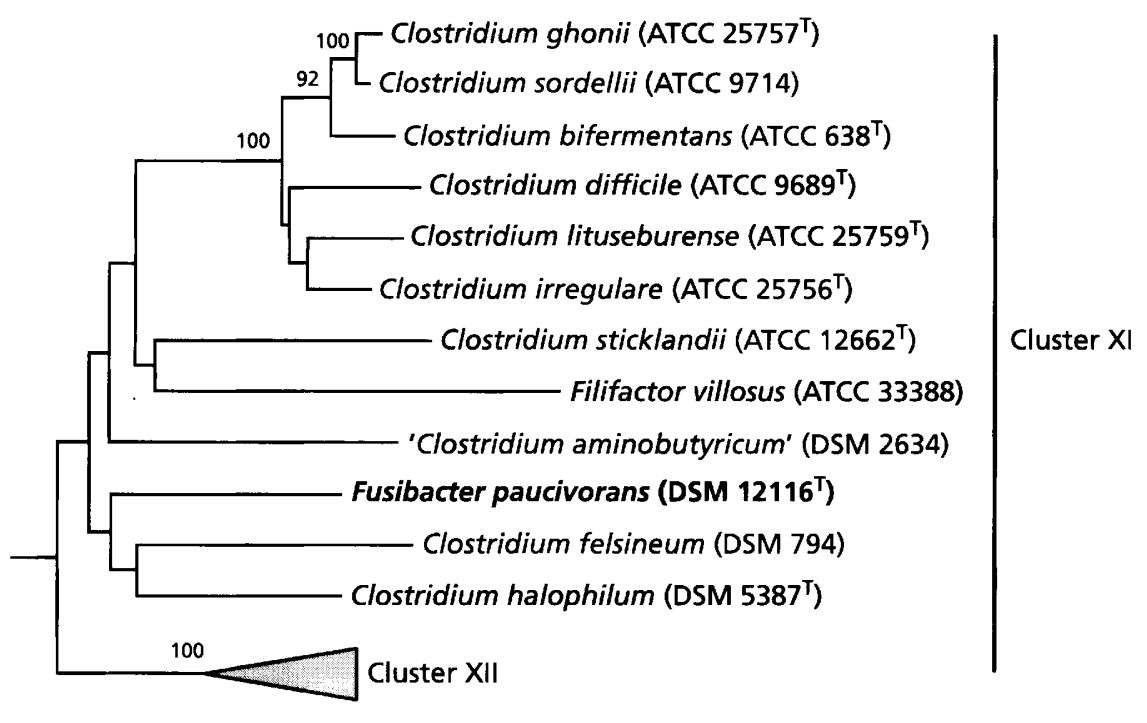

$5 \%$

\begin{abstract}
Fig. 3. Phylogenetic dendrogram indicating the position of Fusibacter paucivorans strain SEBR $4211^{\top}$ (DSM $12116^{\top}$ ) as a member of cluster XI within the radiation of representatives of the low $\mathrm{G}+\mathrm{C}$ content Gram-positive bacteria. The tree was constructed as described in Methods and the two clusters, cluster XI and cluster XII (shown as a triangle), are defined as described by Collins et al. (1994). Sequences were extracted from the Ribosomal Database Project, version 5.0 (Maidak et al., 1996). Bootstrap values are expressed as a percentage of 100 replications and are shown at branching points. Only values above $90 \%$ were considered significant and reported. The scale bar indicates 5 nucleotide substitution per 100 nucleotides.
\end{abstract}

such as Peptostreptococcus anaerobius and Eubacterium tenue. The closest phylogenetic relatives of strain SEBR $4211^{\mathrm{T}}$ are $C$. halophilum ( $90 \%$ similarity) (Fendrich et al., 1990) followed by ' $C$. aminobutyricum' and C. felsineum (Cato et al., 1986) (mean similarity of $89 \%$ ). However, 'C. aminobutyricum' has not yet been taxonomically validated and its status remains unknown (Collins et al., 1994). In addition to the significant phylogenetic difference $(10 \%)$, the following genotypic and phenotypic traits distinguish strain SEBR $4211^{\mathrm{T}}$ from its two nearest taxonomically validated phylogenetic neighbours: (i) strain SEBR $4211^{\mathrm{T}}$ failed to produce spores; (ii) the $\mathrm{G}+\mathrm{C}$ content of DNA from strain SEBR $4211^{\mathrm{T}}$ is $43 \mathrm{~mol} \%$ while that of $C$. halophilum and C. felsineum DNA are 27 and $26 \mathrm{~mol} \%$, respectively; (iii) the substrate range of strain SEBR $4211^{\mathrm{T}}$ is very narrow; (iv) the end products of carbohydrate fermentation are different; in contrast to strain SEBR $4211^{\mathrm{T}}$, ethanol and lactate are produced by $C$. halophilum whereas butanol is produced by $C$. felsineum.

Strain SEBR $4211^{\mathrm{T}}$, when cultured on glucose in the presence of thiosulfate, alters the flow of electrons from butyrate to acetate with concomitant increases in $\mathrm{H}_{2} \mathrm{~S}$ production. The use of thiosulfate as an electron acceptor causes a shift in the flow of electrons, favouring $\mathrm{H}_{2} \mathrm{~S}$ production as already reported for the Thermoanaerobacter species (Fardeau et al., 1996). In the case of strain SEBR $4211^{\mathrm{T}}$, this resulted in channeling of the electrons away from butyrate to acetate, thereby increasing its concentration.

Based on the phylogenetic, phenotypic and genotypic characteristics presented above, we propose placing strain SEBR $4211^{\mathrm{T}}$ as a new species of a new genus within the Clostridiales as Fusibacter paucivorans, gen. nov., sp. nov.

\section{Description of Fusibacter gen. nov.}

Fusibacter (Fu.si.bac'ter. M.L. n. fusum -us a spindle, Gr. dim. n. bakterion a small rod, M.L. neut. n. Fusibacter a small spindle-shaped rod).

Cells are spindle-shaped rods $(1 \times 2-5 \mu \mathrm{m})$. The cells occur singly or in pairs and possess one to four peritrichous flagella. Cells stain Gram-positive. Chemo-organotrophic and obligately anaerobic member of the domain Bacteria. Uses carbohydrates but not peptides, Casamino acids or gelatin. Acetate and butyrate are produced from glucose fermentation. Uses thiosulfate and sulfur as electron acceptors during glucose fermentation. $\mathrm{H}_{2} \mathrm{~S}$ is produced from thiosulfate and sulfur reduction. The $\mathrm{G}+\mathrm{C}$ content of the DNA is $43 \mathrm{~mol} \%$ (as determined by HPLC). The type species is Fusibacter paucivorans.

\section{Description of Fusibacter paucivorans sp. nov.}

Fusibacter paucivorans [pau.ci.vo'rans. L. adj. paucus few; L. part adj. vorans devouring, eating (L. v. vorare to devour, to eat); M.L.part. adj. paucivorans intended to mean a bacterium that utilizes few substrates].

Round colonies (diameter, $1 \mathrm{~mm}$ ) are present after $8 \mathrm{~d}$ incubation at $30^{\circ} \mathrm{C}$. Morphology as for genus Fusibacter. The optimum temperature for growth is $37^{\circ} \mathrm{C}$, temperature range between 20 and $45^{\circ} \mathrm{C}$. The optimum $\mathrm{pH}$ is $7 \cdot 3$, growth occurs between $\mathrm{pH} 5.7$ and $\mathrm{pH} 8.0$. Halotolerant; the optimum sodium chloride concentration for growth is between 0 and $3 \%(\mathrm{w} / \mathrm{v})$, growth occurs at $\mathrm{NaCl}$ concentrations ranging between 0 and $10 \%$. Utilizes cellobiose, fructose, glucose, D-mannitol and D-ribose but not arabinose, galactose, lactose, maltose, mannose, sorbose, sucrose, rhamnose, trehalose, xylose, acetate, butyrate, lactate or propionate. Requires yeast extract for growth. The end products of glucose fermentation in the presence 
of yeast extract and bio-Trypticase are butyrate, acetate, $\mathrm{CO}_{2}$ and $\mathrm{H}_{2}$. Isolated from an oil-producing well. The type strain is SEBR $4211^{\mathrm{T}}$ (= DSM $12116^{\mathrm{T}}$ ).

\section{ACKNOWLEDGEMENTS}

The financial assistance in part to B.K.CP. from the Australian Research Council is gratefully acknowledged. We thank P. A. Roger for his comments on the manuscript and J. L. Cayol for helpful discussion.

\section{REFERENCES}

Andrews, K. T. \& Patel, B. K. C. (1996). Fervidobacterium gondwanense sp. nov., a new thermophilic anaerobic bacterium isolated from nonvolcanically heated geothermal waters of the Great Artesian Basin of Australia. Int J Syst Bacteriol 46, 265-269.

Balch, W. E., Fox, G. E., Magrum, J., Woese, C. R. \& Wolfe, R. S. (1979). Methanogens: re-evaluation of a unique biological group. Microbiol Rev 43, 260-296.

Bernard, F. P., Connan, J. \& Magot, M. (1992). Indigenous microorganisms in connate water of many oil fields: a new tool in exploration and production techniques. In Proceedings of the 67th Annual Technical Conference and Exhibition Society of Petroleum Engineers, pp. 1-10. Richardson, TX: Society of Petroleum Engineers.

Cato, E. P., George, W. L. \& Finegold, S. M. (1986). Genus Clostridium Prazmowski 1880, 23 $3^{\mathrm{AL}}$. In Bergey's Manual of Systematic Bacteriology, vol. 2, pp. 1141-1200. Edited by P. H. A. Sneath, N. S. Mair, M. E. Sharpe \& J. G. Holt. Baltimore: Williams \& Wilkins.

Cayol J.-L., Ollivier, B., Lawson Anani Soh, A. \& 7 other authors. (1994). Haloincola saccharolytica subsp. senegalensis subsp. nov., isolated from the sediments of a hypersaline lake, and emended description of Haloincola saccharolytica. Int J Syst Bacteriol 44, 805-811.

Collins, M. D., Lawson, P. A, Willems, A., Cordoba, J. J., Fernandez-Garayzabal, J., Garcia, P., Cai, J., Hippe, H. \& Farrow, J. A. E. (1994). The phylogeny of the genus Clostridium: proposal of five new genera and eleven new species combinations. Int $J$ Syst Bacteriol 44, 812-826.

Cord-Ruwisch, R. (1985). A quick method for the determination of dissolved and precipitated sulfides in cultures of sulfatereducing bacteria. J Microbiol Methods 4, 33-36.

Crolet, J.-L. \& Magot, M. (1996). Non SRB sulfidogenic bacteria from oil field production facilities. Mater Performance March, 60-64.

Davydova-Charakhch'yan, I. A., Mileeva, A. N., Mityushina, L. L. \& Belyaev, S. S. (1993). Acetogenic bacteria from oil fields of Tartaria and western Siberia. Microbiology (English translation of Mikrobiologiya) 61, 306-315.

Fardeau, M.-L., Cayol, J.-L., Magot, M. \& Ollivier, B. (1993). $\mathrm{H}_{2}$ oxidation in the presence of thiosulfate, by a Thermoanaerobacter strain isolated from an oil-producing well. FEMS Microbiol Lett 113, 327-332.

Fardeau, M.-L., Faudon, C., Cayol, J.-L., Magot, M., Patel, B. K. C. \& Ollivier, B. (1996). Effect of thiosulfate as electron acceptor on glucose and xylose oxidation by Thermoanaerobacter finnii and a Thermoanaerobacter sp. isolated from oil field water. Res Microbiol 147, 159-165.

Fardeau, M.-L., Ollivier, B., Patel, B. K. C., Magot, M., Thomas, P., Rimbault, A., Rocchiccioli, F. \& Garcia, J.-L. (1997). Thermotoga hypogea sp. nov., a xylanolytic, thermophilic bacterium from an oil-producing well. Int J Syst Bacteriol 47, 1013-1019.

Felsenstein, J. (1993). PHYLIP (Phylogenetic Inference Package) version 3.51c. Seattle: Department of Genetics, University of Washington.

Fendrich, C., Hippe, H. \& Gottschalk, G. (1990). Clostridium halophilium $\mathrm{sp}$. nov. and $C$. litorale sp. nov., an obligate halophilic and a marine species degrading betaine in the Stickland reaction. Arch Microbiol 154, 127-132.

Holloway, S. L., Faw, G. M. \& Sizemore, R. K. (1980). The bacterial community composition of an active oil field in the Northwestern Gulf of Mexico. Marine Pollut Bull 11, 153-156.

Hungate, R. E. (1969). A roll tube method for cultivation of strict anaerobes. In Methods in Microbiology, pp. 117-132, Vol. 3b. Edited by J. R. Norris \& D. W. Ribbons. New York: Academic Press.

Jeanthon, C., Reysenbach, A.-L., L'Haridon, S., Gambacorta, A., Pace, N. R., Glénat, P. \& Prieur, D. (1995). Thermotoga subterranea sp. nov., a new thermophilic bacterium isolated from a continental oil reservoir. Arch Microbiol 164, 91-97.

Jukes, T. H. \& Cantor, C. R. (1969). Evolution of protein molecules. In Mammalian Protein Metabolism, pp. 211-232. Edited by H. N. Munro. New York: Academic Press.

L'Haridon, S., Reysenbach, A.-L., Glénat, P., Prieur, D. \& Jeanthon, C. (1995). Hot subterranean biosphere in a continental oil reservoir. Nature 377, 223-224.

Love, C. A., Patel, B. K. C., Nichols, P. D. \& Stackebrandt, E. (1993). Desulfotomaculum australicum sp. nov., a thermophilic sulfatereducing bacterium isolated from the Great Artesian Basin of Australia. Syst Appl Microbiol 16, 244-251.

Magot, M., Carreau, L., Cayol, J.-L., Ollivier, B. \& Crolet, J.-L. (1994). Sulphide-producing, not sulphate-reducing anaerobic bacteria presumptively involved in bacterial corrosion. In Proceedings of the 3rd European Federation of Corrosion Workshop on Microbiol Corrosion. Edited by C. A. C. Sequeira. London: The Institute of Materials.

Magot, M., Fardeau, M.-L., Arnauld, O., Lanau, C., Ollivier, B., Thomas, P. \& Patel, B. K. C. (1997a). Spirochaeta smaragdinae $\mathrm{sp}$. nov., a new mesophilic strictly anaerobic spirochete from an oil field. FEMS Microbiol Lett 155, 185-191.

Magot, M., Ravot, G., Campaignolle, X., Ollivier, B., Patel, B. K. C., Fardeau, M.-L., Thomas, P., Crolet, J.-L. \& Garcia, J.-L. (1997b). Dethiosulfovibrio peptidovorans gen. nov., sp. nov., a new anaerobic, slightly halophilic, thiosulfate-reducing bacterium from corroding offshore oil wells. Int $J$ Syst Bacteriol 47, 818-824.

Maidak, B. L., Olsen, G. J., Larsen, N., Overbeek, R., McCaughey, M. J. \& Woese, C. R. (1996). The ribosomal database project (RDP). Nucleic Acids Res 24, 82-85.

Mesbah, M., Premachandran, U. \& Whitman, W. B. (1989). Precise measurement of the $\mathrm{G}+\mathrm{C}$ content of deoxyribonucleic acid by high-performance liquid chromatography. Int $J$ Syst Bacteriol 39, 159-167.

Ravot, G., Magot, M., Fardeau, M.-L., Patel, B. K. C., Prensier, G., Egan, A., Garcia, J.-L. \& Ollivier, B. (1995a). Thermotoga elfii $\mathrm{sp}$. nov., a novel thermophilic bacterium from an African oilproducing well. Int $J$ Syst Bacteriol 45, 308-314.

Ravot, G., Ollivier, B., Magot, M., Patel, B. K. C., Crolet, J.-L., Fardeau, M.-L. \& Garcia, J.-L. (1995b). Thiosulfate reduction, an important physiological feature shared by members of the order Thermotogales. Appl Environ Microbiol 61, 2053-2055.

Ravot, G., Magot, M., Ollivier, B., Patel, B. K. C., Ageron, E., 
Grimont, P. A. D., Thomas, P. \& Garcia, J.-L. (1997). Haloanaerobium congolense sp. nov., an anaerobic, moderately halophilic, thiosulfate- and sulfur-reducing bacterium from an African oil field. FEMS Microbiol Lett 147, 81-88.

Redburn, A. C. \& Patel, B. K. C. (1993). Phylogenetic analysis of Desulfotomaculum thermobenzoicum using polymerase chain reaction-amplified 16S rRNA-specific DNA. FEMS Microbiol Lett 113, 81-86.

Stetter, K. O., Huber, R., Blöchl, E., Kurr, M., Eden, R. D., Fielder, M., Cash, H. \& Vance, I. (1993). Hyperthermophilic Archaea are thriving in deep North Sea and Alaskan oil reservoirs. Nature $365,743-745$. 